\title{
Using LAMS to Link Learners in an E-Learning Environment
}

Learning Activity Management System

\author{
Maree A. Skillen \\ Shore (S.C.E.G.S), North Sydney, Australia
}

\begin{abstract}
As new technologies evolve and innovations emerge, educators' understandings about teaching and learning in the electronic environment are constantly challenged. Linking learners in both independent and collaborative settings becomes a significant pedagogical undertaking. A key component to gaining an enhanced understanding of this process involves the concept of Learning Design which has been described by Dalziel (2003b) as having "the potential to revolutionise e-learning by capturing the 'process' of education, rather than simply content". An example of a Learning Design system is the Learning Activity Management System or 'LAMS'. This paper will provide a brief outline of LAMS and a discussion that focuses on its use in a pre-service ICT teacher education course unit and with secondary students in a school-based Computing course. A sample learning sequence to be utilised by learners and developed for a selected content area will be briefly outlined. The aim for educators using LAMS is to create learning experiences that actively involve learners and improve educational outcomes. Early trials of this system suggest it allows learning and motivation to be enhanced and that there is a willingness exhibited by individuals to engage in tasks and whole group discussions. It is argued that teaching and learning can be enriched as the technological tools and pedagogical processes are brought together in appropriate ways.
\end{abstract}

Keywords: E-learning, LAMS (Learning Activity Management System), learning design, pre-service teachers.

\section{INTRODUCTION}

"Education is one of the fastest growing economic and social sectors in the world, and the use of new technologies is an integral and driving component of that growth".

(McCreal and Elliott, 2004, p. 115) 


\section{E-LEARNING}

Whilst there is no universally accepted definition for e-learning, at its broadest, it is seen to be the use of ICTs (Information and Communication Technologies) to support teaching and learning. Siemens (2002) supports this by referring to e-learning as being 'the marriage of technology and education'. E-learning is often restricted to the online medium and is used widely to support different delivery modes in educational institutions.

Charles Clarke (DfES-UK, 2003) describes e-learning as having the potential to revolutionise the way we teach and how we learn. It is already present in schools, colleges, Universities, the workplace and in our homes. If someone is learning in a way that uses ICTs, then they are using e-learning. The concept of e-learning is important because individuals are finding and realising that this form of learning can make a significant difference in terms of how quickly a skill is mastered, the ease with which study can be undertaken and how much they enjoy learning (DfES-UK, 2003, p. 3). As Gerry White points out the benefits e-learning brings such as empowering the learner, providing choices and opportunities for collaboration across boundaries - make it an important player in $21^{\text {st }}$ century education.

\subsection{LEARNING DESIGN}

Learning Design has emerged as one of the most significant recent developments in e-learning. Sloep (2002) refers to the teaching of Learning Design as being based on the general idea of people doing activities with resources. This shifts the emphasis from content driven single learner programs to more collaborative learning activity sequences. As Dalziel (2004) explains Learning Design is a name being given to a new field of e-learning technology based on 'best practice process'. He refers to it as providing "a glimpse at the ways of describing multi-learner sequences and the tools required to support these".

Learning Design can be considered to be a sequence of collaborative learning activities whereby each of the tasks can be stored, re-used and customised for alternative content or focus areas in a very short frame of time. In terms of the school context, Learning Design can be thought of as a series of lesson plans that can incorporate single learner content, but also collaborative tasks such as polling, forum, chat and small group discussions.

\subsection{LAMS}

LAMS (Learning Activity Management System) is a collaborative online learning system which was developed in 2002, by WebMCQ Pty Ltd in conjunction with Macquarie University. It allows for the establishment of a repository of learning materials where individual resources, tasks and constructed sequences to engage learners either independently or collaboratively, are stored for easy access or use by teachers and learners 
prior to activating them within a classroom environment through the use of ICT. Teachers have access to a facility for creating their own lesson activities or for reviewing deposited materials and then adapting these templates into alternative lesson sequences. This can be done quite quickly and numerous lessons can be generated from similar or very differently constructed learning sequences.

LAMS is a server-based application that can be accessed from any computer via a web browser. LAMS enables:

- Students to work independently and/or collaborate on-line through activities created using a tool set designed specifically for the purposes of quality on-line learning.

- Teachers to design learning sequences in accordance with sound pedagogical practices in a learning environment that can be enriched with local and web-based resources.

The LAMS application is divided into four levels of functionality (refer to diagram 1). These include:

1.The Author area is where teachers can design and modify learning activity sequences using specifically designed learning tools, such as discussion boards, research activities, group collaboration tasks.

2. The Monitor area provides a mechanism for teachers to assign learners to groups, activate learning sequences for specified groups, monitor individual progress through the learning sequence.

3.The Learner area accommodates individual and group learning sequences where students complete tasks in sequential order.

4. The Administration area is devoted to system administration tasks such as creating users and managing user groups.

\section{LAMS 2 Architecture Overview}

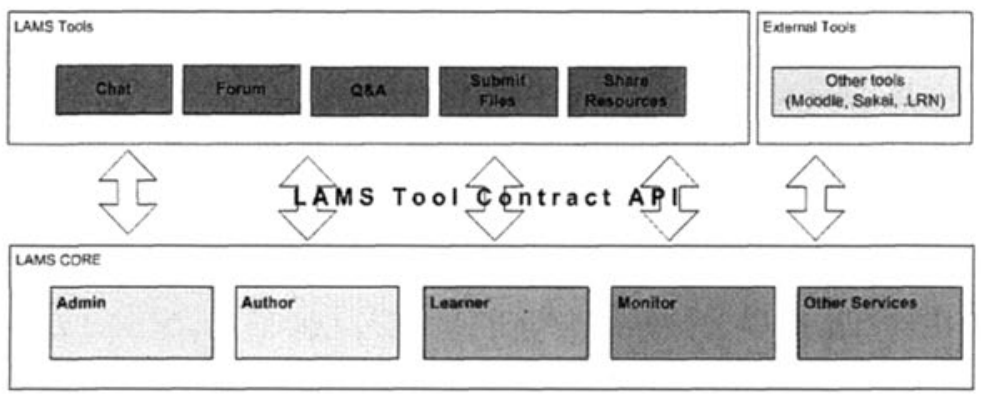

Diagram 1 (Dalziel, 2006)

\subsection{USING LAMS WITH PRE-SERVICE TEACHERS}

Pre-service Secondary ICT teachers' were required as part of an undergraduate teaching unit entitled 'ICT in the Secondary School' to develop a lesson using LAMS. In particular, students were required to 
demonstrate a basic understanding of LAMS and its relevance to e-learning; identify an appropriate syllabus and series of outcomes to use with a LAMS sequence; develop and implement a simple LAMS sequence; describe the process used to plan and implement a LAMS sequence; identify for the lesson/unit of work links to the 7-10 syllabus and, reflect on the importance of the learning process in the construction of a LAMS sequence.

\subsubsection{A LAMS Lesson Example}

Pre-service ICT teachers were required to become familiar with the NSW Board of Studies Stage 6 ICT syllabuses in order to identify a component related to legal, social or ethical issues that would benefit from the use of a LAMS interface as the lesson delivery mode. It is clearly identified that LAMS is well suited to "actively engage students in reflective activities that require them to work through ethical issues" (Meyenne, 2000), and LAMS can sustain a collaborative environment (when certain tools are invoked), so a group project within the Information Processes and Technology (IPT) and/or Software Design and Development (SDD) syllabus involving ethical decisions was sought. The school magazine/newsletter project from the Stage 6 Preliminary IPT syllabus was deemed as being the most suitable option for this task.

Having selected a component of the syllabus to be addressed, the next stage was to derive a lesson plan that best served the students' learning needs. The following were taken into account when planning the lesson:

1.Cognitive implications i.e. when students are required to use higher order (abstract) thinking, they require cognitive strategies and cognitive processing opportunities (Rosenshine, 1995).

2. Suggestions from Meyenne's methodology for the teaching of ethics in schools (Meyenne, 2000).

3.An online learning process recommending preparation, activities, interaction, and a transfer to real life (Anderson and Elloumi, 2004).

4.The NSW Quality Teaching Program (NSW Department of Education, 2003) that promotes intellectual quality, quality learning environments, and a context that holds significance to students.

5.The use of project management and team developing skills.

Hurst and Thomas, in their article "Developing team skills and accomplishing team projects online" (Anderson and Elloumi, 2004), identify the following as "the key ingredients for successful online teaming in learning" include an agreement on how members will work together, individual and group accountability, flexibility, the monitoring of progress, and social interaction. Each of these characteristics were incorporated into the assignment task developed for the specified course unit.

\subsubsection{LAMS Activity Tools Selection Process}

Rosenshine (1995) produced an article entitled "Advances in research on Instruction" in which he identifies six steps that best help students learn, 
particularly subjects that require higher-order thinking strategies. This article provided a framework for the development of a LAMS lesson, and the LAMS tools used in the Code of Ethics sequence were chosen specifically because they provided the functionality required for each step, as outlined below.

\begin{tabular}{|l|l|}
\multicolumn{1}{|c|}{$\begin{array}{c}\text { Rosenshine's Effective Teaching } \\
\text { Strategies }\end{array}$} & \multicolumn{1}{c|}{$\begin{array}{c}\text { LAMS Tool with the required } \\
\text { functionality }\end{array}$} \\
\hline Present new material in small steps. & $\begin{array}{l}\text { Multiple noticeboards and Q\&A are } \\
\text { used to dissect information into } \\
\text { manageable quantities. }\end{array}$ \\
\hline $\begin{array}{l}\text { Help students develop an organisation for } \\
\text { the new material. }\end{array}$ & $\begin{array}{l}\text { An example Code of Ethics is on hand } \\
\text { for the teacher to show as a guide. }\end{array}$ \\
\hline $\begin{array}{l}\text { Guided student practice - provide } \\
\text { opportunity for student processing. }\end{array}$ & $\begin{array}{l}\text { The shared resources and polling } \\
\text { activities give students cognitive } \\
\text { processing opportunities. }\end{array}$ \\
\hline $\begin{array}{l}\text { When teaching higher order tasks, provide } \\
\text { students with cognitive strategies. }\end{array}$ & $\begin{array}{l}\text { The noticeboard tool provides an ideal } \\
\text { medium for suggesting strategies when } \\
\text { they are most needed. }\end{array}$ \\
\hline $\begin{array}{l}\text { Help students to use cognitive strategies } \\
\text { by providing them with procedural } \\
\text { prompts. }\end{array}$ & $\begin{array}{l}\text { The polling activity is an ideal way to } \\
\text { offer students a procedural prompt. }\end{array}$ \\
\hline $\begin{array}{l}\text { Provide students with opportunity for } \\
\text { extensive student practice. }\end{array}$ & $\begin{array}{l}\text { The progress mechanism allows students } \\
\text { to revisit activities if needed. In this } \\
\text { case, the extent of student practice is } \\
\text { limited by time rather than process. }\end{array}$ \\
\hline
\end{tabular}

Table 1: Comparison of Rosenshine's Teaching Strategies and LAMS Functionality

\section{FROM THEORY INTO PRACTICE}

Many of the pedagogical practices espoused by the main schools of learning are incorporated in online learning (Anderson and Elloumi, 2004). In essence, the main learning theories can be summarised as: behaviourists favour teacher-directed learning sequences; cognitivists endorse the use of internalised learning and personal reflection and, constructivists encourage active rather than passive learning.

By way of distilling vast quantities of pedagogical theory and research, the NSW Department of Education have prepared a Quality Teaching Program (QTP) for NSW Public Schools. This model identifies three key issues to ensure quality student learning. The issues are intellectual quality, quality learning environment and, significance.

The "Code of Ethics" LAMS sequence developed by a student for the preservice ICT teacher education assignment embraced each of the main learning theories as well as elements of the key issues identified by the Quality Teaching Program. 
The teacher can ensure the intellectual quality of the lesson through:

- Articles and web pages to be reviewed or researched by the students are pre-selected and screened as being appropriate for the lesson.

- The sequence of learning activities is presented to students in a prescribed order. The activities are designed to meet specific learning objectives and the sequence ensures that pre-requisite knowledge is gained before subsequent learning activities are attempted (in accordance with behaviourist practices).

LAMS provided a tool to enhance the quality of the learning environment. This was demonstrated by:

- Individual contributions to group work could be monitored and assessed.

- Students were given the opportunity to self-regulate their learning by:

- Conducting independent research of web-sources in a supervised environment.

- Having time to reflect on materials presented (exemplifying cognitivist ideology).

- Assuming responsibility to accomplish tasks within a group project without teacher intervention.

In accordance with constructionist theory, the project had inherent significance and encouraged active participation.

- The learning activities were directly linked to a scenario that was relevant to the school-aged students (that being the creation of a Code of Ethics to apply to the production of a school newsletter).

- Peer-to-peer and teacher feedback that recognised and gave value to all student contributions was encouraged.

In conclusion, The "Code Of Ethics" LAMS sequence provided students with the opportunity to explore, consider, discuss and synthesise ethics in an environment where each student could contribute, reflect and achieve both individually and as a valued team member.

\section{DEVELOPING A LEARNING ACTIVITY SEQUENCE}

To illustrate more specifically the implementation of Learning Design an example of a learning activity sequence, "Take a Stand", has been constructed to involve secondary IPT students collaboratively in considering issues, responding with an opinion and supporting their individual viewpoints. Table 2 summarises some of the key aspects to be considered in the planning process of a LAMS learning sequence. 


\begin{tabular}{|l|l|}
\hline LAMS Activity Title & Take a Stand \\
\hline Year Level & Year $11^{*}$ \\
\hline $\begin{array}{l}\text { Suggested Duration } \\
\text { (Note: this will be influenced by the length of a } \\
\text { lesson and the students application to the task) }\end{array}$ & 4 to 6 lessons \\
\hline Subject Area Focus & $\begin{array}{l}\text { Information Processes and Technology: } \\
\text { Preliminary } \rightarrow \text { Social and ethical issues }\end{array}$ \\
\hline Introduction to Task & $\begin{array}{l}\text { As individuals we often agree and } \\
\text { disagree on various issues depending } \\
\text { upon our personal views to a given } \\
\text { situation or topic. This activity will } \\
\text { require you to consider a statement and to } \\
\text { then 'Take a Stand'. There is no right or } \\
\text { wrong, but individuals must be able to } \\
\text { justify appropriately why they agree, } \\
\text { disagree or are neutral about the selected } \\
\text { statement. All opinions need to be } \\
\text { supported with valid reasons by an } \\
\text { individual learner. }\end{array}$ \\
\hline \multirow{3}{*}{$\begin{array}{l}\text { Suggested lesson structure for } \\
\text { completion of the sequence }\end{array}$} & $\begin{array}{l}\text { Lesson 1: Initial Noticeboard + Polling } \\
\text { Lesson 2: Chat \& Scribe } \\
\text { Lesson 3: Q\&A + Read Noticeboard ( } \# 2) \\
\text { Lesson 4: Read Noticeboard (\#2) }+ \\
\text { discuss } \\
\text { Lesson 5: Submission + general } \\
\text { discussion } \\
\text { Lesson 6: Follow-up discussion }\end{array}$ \\
\hline
\end{tabular}

Table 2: Planning for a LAMS Sequence (Note: * the task shown could be adapted for younger students or made more complex to challenge older students.)

Table 3 summarises each of the LAMS activity tools used in 'Take a Stand' and aims to identify the application of each within the short sequence constructed.

\begin{tabular}{|l|l|l|}
\hline \multicolumn{1}{|c|}{ Tool } & $\begin{array}{l}\text { Description of LAMS Activity } \\
\text { Tool }\end{array}$ & $\begin{array}{l}\text { Application of LAMS Activity } \\
\text { Tool }\end{array}$ \\
\hline Noticeboard & $\begin{array}{l}\text { - } \begin{array}{l}\text { Simple text to learner } \\
\text { relating to the sequence and } \\
\text { operation. }\end{array} \\
\begin{array}{l}\text { Polling } \\
\text { with a list of options to "vote" } \\
\text { on. } \\
\text { - Shows collated learner } \\
\text { responses. }\end{array}\end{array}$ & $\begin{array}{l}\text { Introductory text for learners to } \\
\text { put a context to the activity that } \\
\text { they are about to engage in. }\end{array}$ \\
\hline $\begin{array}{l}\text { Separately for learners to read } \\
\text { and to respond to. ie. they will } \\
\text { vote or 'Take a Stand' (agree, } \\
\text { neutral, disagree) for each of the } \\
\text { issues in turn. } \\
\text { Example: "We would have } \\
\text { more unemployment if } \\
\text { computers did not exist" }\end{array}$ \\
\hline Chat \& Scribe & $\begin{array}{l}\text { - A live chat is combined with } \\
\text { a scribe tool for collating the }\end{array}$ & $\begin{array}{l}\text { Learners are posed with a series } \\
\text { of questions to respond through }\end{array}$ \\
\hline
\end{tabular}




\begin{tabular}{|c|c|c|}
\hline & $\begin{array}{l}\text { chat group's view on a question } \\
\text { created by the teacher. } \\
\text { - Use in small groups: creates } \\
\text { a parallel chat and scribe area. } \\
\text { - Shows the outcome of each } \\
\text { group on a whole class page } \\
\text { (viewable by all learners). }\end{array}$ & $\begin{array}{l}\text { collaborating in a group } \\
\text { situation. The question may } \\
\text { include, for example: } \\
\text { "Many people believe that there } \\
\text { is a danger that the computer } \\
\text { technology revolution could be } \\
\text { used as a tool by the wealthy } \\
\text { industrial nations to further } \\
\text { exploit developing nations. Do } \\
\text { you believe there are ways in } \\
\text { which wealthy nations could be } \\
\text { preventing this to occur?" }\end{array}$ \\
\hline$Q \& A$ & $\begin{array}{l}\text { - Teacher poses a question to } \\
\text { learners individually } \\
\text { - Learner enters a response } \\
\text { - Learners view all responses } \\
\text { of peers on a single answer } \\
\text { screen }\end{array}$ & $\begin{array}{l}\text { Example question for learner to } \\
\text { respond to may include } \\
\text { "Computer users are sometimes } \\
\text { able to gain unauthorised access } \\
\text { to computer systems. What } \\
\text { implications are there if this } \\
\text { should occur?" }\end{array}$ \\
\hline $\begin{array}{l}\text { Noticeboard } \\
(\# 2)\end{array}$ & $\begin{array}{l}\text { Simple text to learner } \\
\text { relating to the sequence and } \\
\text { operation }\end{array}$ & $\begin{array}{l}\text { Your final task, to be completed } \\
\text { for homework and then } \\
\text { submitted in the next lesson, is } \\
\text { to write an essay in response to } \\
\text { the following statement: } \\
\text { "Learning about computers } \\
\text { should be compulsory in } \\
\text { schools. Do you agree?" Your } \\
\text { answer should state the reasons } \\
\text { for your support or lack of } \\
\text { support about the given } \\
\text { statement. Explanations } \\
\text { provided should be well } \\
\text { discussed". }\end{array}$ \\
\hline Submission & $\begin{array}{l}\text { Learners submit a file for } \\
\text { assessment by the teacher - for } \\
\text { example, an essay or report } \\
\text { Note: the monitoring } \\
\text { workspace provides assistance } \\
\text { to the teacher with managing } \\
\text { the marking process for } \\
\text { submissions. }\end{array}$ & $\begin{array}{l}\text { Next lesson: learners should be } \\
\text { able to submit a completed } \\
\text { essay to the question stated in } \\
\text { Noticeboard (\#2). This } \\
\text { homework item will be used for } \\
\text { assessment purposes for the } \\
\text { learner. }\end{array}$ \\
\hline
\end{tabular}

Table 3: Description and details of LAMS activity tools used in the sample sequence 'Take a Stand'

\section{EARLY TRIALS OF LAMS}

Beta versions of LAMS were tested widely in a variety of primary and secondary schools, colleges and Universities across Australia, Canada and the UK (Kraan, 2003). From these trials, preliminary findings have indicated that the system has assisted in increasing the participation rate of some students 
dramatically, along with enhancing the collaborative interactions of learners. Dalziel (2003a) found that initial evaluations of LAMS in K-12 schools and University environments during 2003 indicated that there was a profound impact on both student learning and teachers' conceptualisation of the learning process. Research into this impact is currently ongoing, but one early example from Kemnal Technology College, a boys' secondary school in the UK, found in a pilot evaluation that only $15 \%$ of students were willing to discuss ideas in front of their peers in the classroom, but over $80 \%$ of the same students were willing to discuss their ideas within LAMS (Gibbs, 2004). Interviews with teaching staff at Kemnal Technology College suggest that LAMS is one of the main contributing factors for their students becoming more active participants in classroom discussions and collaborative activities (Gibbs, 2004).

\section{CONCLUSION}

As with most things involving technology, there were limitations within the LAMS system that the design team have overcome in later versions of the software. The subsequent development of the tools and additional features within the system, in recent times, have added a greater depth and dimension to the LAMS experience for both learners and teachers. Whilst there may be drawbacks in educational institutions relating to the access and equity of ICTs, the advantages of using LAMS far outweigh the disadvantages. The advantages relate to the learning experiences of individuals where collaboration and the promotion of learner involvement are encouraged and cognitive skills are enhanced. The success of LAMS is such that it is now open-software and far more widely used in the area of education both within Australia and beyond.

The process of developing a unit of work in LAMS encourages teachers to reflect on their pedagogy and to find ways to engage their learners. They also have the option of using templates designed by other educators either as they exist or through easy adaptation to their own needs and specific subject areas. The use of LAMS in the classroom is a means of realising the potential held by technology for education in the $21^{\text {st }}$ century.

\section{REFERENCES}

Anderson, T. and Elloumi, F. (2004). Theory and practice of online learning. Athabasca University: Canada. Retrieved March 21, 2004, from http://cde.athabascau.ca/online book index.html

Dalziel, J. (2003a, December). Implementing Learning Design: The Learning Activity Management System (LAMS). Paper presented at the ASCILITE 2003 conference, Adelaide, South Australia.

Dalziel, J. (2003b). LAMS: Teacher Guide - Draft. Macquarie University: MELCOE, Sydney. 
Dalziel, J. (2004, January). The Learning Design Revolution: Implementing the Learning Activity Management System (LAMS). Paper presented at the Oxford Learning Design workshop, Oxford, UK.

Dalziel, J. (2006). Modelling a team-based astronomy task using LAMS. Presentation for ICALT 2006, Kerkrade, Netherlands, $5^{\text {th }}$ July, 2006.

Department for Education and Skills-UK [DfES-UK]. (2003). Towards a Unified e-Learning Strategy: Consultation Document Executive Summary. Retrieved June 4, 2004, from http://ferl.becta.org.uk

Gibbs, D. (2004). Electronic selves: gender and anonymity as factors in e-learning. Paper to be presented at the Style Council Conference 2004. (Publication forthcoming)

Kemnal Technology College, UK. Retrieved June 9, 2004, from http://www.ktc. bromley.sch.uk

Kraan, W. (2003). Learning design inspiration: Retrieved March 21, 2004, from http:/www.cetis.ac.uk/content2/20031105152011/printArticle

McGreal, R. and Elliott, M. (2004). Technologies of Online Learning (E-Learning). In Anderson, T. and Elloumi, F. (2004). Theory and practice of online learning. Athabasca University: Canada. Retrieved March 21, 2004, from http://cde.athabascau.ca /online_book/index.html (pp. 115-135)

Meyenne, A. (2000, November). A proposed methodology for the teaching of information technology ethics in schools, Australian Educational Computing 15, 2 (pp. 15-20).

NSW Board of Studies (BOS). Syllabus Documents for Stage 6 IPT and SDD. Retrieved October 14, 2005, from http://www boardofstudies.nsw edu.au/syllabus hsc/index.html

NSW Department of Education (2003). Quality teaching in NSW public schools: A classroom practice guide. Retrieved October 14, 2005, from http:/detww.det.nsw.edu.au /directorates/profcurr/welcome.html

Rosenshine, B. (1995). Advances in research on instruction. The Journal of Educational Research, 88, (pp. 262-268).

Siemens, G. (2002). Instructional Design in E-learning. Retrieved March 21, 2004, from http:/ www elearnspace.org/Articles/InstructionalDesign.htm

Sloep, P. (2002). IMS Learning Design Update. Retrieved June 9, 2004, from http//www.cetis.ac.uk/groups/20010809_/44711/FR200211601_20327

White, G. (Ed). The changing landscape: e-learning in schools. Retrieved June 9, 2004, from http://www.educationau.edu.au/papers/changing landscape gw.pdf 